\title{
Effects of short-term exposure to paralytic shellfish toxins on clearance rates and toxin uptake in five species of New Zealand bivalve
}

\author{
Andrea M. Contreras ${ }^{a, b},{ }^{*}$, Islay D. Marsden ${ }^{c}$ and Murray H. G. Munro ${ }^{d}$ \\ ${ }^{a}$ School of Biological Sciences, University of Canterbury, Christchurch, New Zealand. \\ ${ }^{\mathrm{b}}$ Present address: IFREMER, Laboratoire Phycotoxines, Nantes, France. \\ ${ }^{\mathrm{c}}$ School of Biological Sciences, University of Canterbury, Christchurch, New Zealand. \\ ${ }^{\mathrm{d}}$ Department of Chemistry, University of Canterbury, Christchurch, New Zealand.
}

*Corresponding Author: Andrea M. Contreras, Tel: +33 (02) 40374254, Fax: +33 (02) 40374073, email address : andrea.contrerasg@gmail.com

\begin{abstract}
:
Algal blooms produced by toxic dinoflagellates have increased worldwide, resulting in economic losses to aquaculture and fisheries. Bivalve species differ in their ability to feed on toxin-producing dinoflagellates and this could result in differences in toxin accumulation among species. In New Zealand, the effects of paralytic shellfish poisoning (PSP) toxins on the physiology of bivalve molluscs are relatively unknown. We hypothesised that the feeding responses of five New Zealand bivalve species exposed to PSP-toxic dinoflagellates would be species-specific, affecting their accumulation of toxins. Each species was exposed to toxic and non-toxic species of Alexandrium spp. and clearance rate used as an index of sensitivity to PSP toxins. Clearance rates for the mussel Perna canaliculus and the clam Dosinia anus were unaffected by the presence of toxic dinoflagellates, whereas the rate in the scallop Pecten novaezelandiae decreased significantly. There were variable results for the clam Paphies donacina and the oyster Ostrea chilensis. Species-specific biotransformation of PSP-toxins had taken place in the bivalve tissues. We conclude that the rate of accumulation of PSP toxins in the tissues of the bivalve species was influenced by their feeding behaviour and the different chemical processes that had taken place in their tissues.
\end{abstract}

Keywords: biotransformation, decarbamoylation, Dosinia anus, epimerisation, Ostrea chilensis, Paphies donacina, Pecten novaezelandiae, Perna canaliculus. 


\section{Introduction}

Algal blooms have increased in frequency, intensity and geographical distribution worldwide, causing severe economic losses to aquaculture, fisheries and tourism operations and having major environmental and human health impacts (Hallegraeff 1993; Rodríguez Rodríguez et al. 2011). It is well known that the accumulation of Paralytic Shellfish Poisoning (PSP) toxins in bivalve is speciesspecific and the differences in toxicity between species can be as much as 100 -fold (Bricelj and Shumway 1998). Physiological processes and bioconversions of PSP-toxins are believed to be the major factors controlling the tissue levels of the toxins. Comparative studies on PSP-toxin profiles often show significant differences between the causative dinoflagellates and contaminated bivalves, thus indicating active toxin metabolism in shellfish (Oshima et al. 1990; Cembella et al. 1994; Elke et al. 2007).

The ability of shellfish to accumulate toxins may largely depend on filtration rates, the individual species' capabilities for selective ingestion and/or absorption of toxic cells as well as the density and distribution of the toxic dinoflagellates in the water column (Shumway et al. 1985). Sensitivity to PSP-toxins in bivalves has been evaluated using three different types of responses. Firstly, there are neurological responses, or in vivo blocking of the action potential of nerve fibres exposed to saxitoxin (STX) (Twarog et al. 1972; Kvitek and Beitler 1991). Secondly, there are physiological responses, primarily the inhibition of clearance (feeding) rates elicited by toxic dinoflagellates (Bricelj and Shumway 1998, Navarro and Contreras 2010). Thirdly, there are behavioral responses such as inhibition of siphon retraction and impaired ability to burrow in sediments in infaunal bivalves (Bricelj et al. 1996, 2011). Several recent studies have tested altered shell valve activity in bivalves following harmful microalgal exposure (Nagai et al. 2006; Basti et al. 2009; Tran et al. 2010; Heberkorn et al. 2011).

In general, bivalve species that are insensitive to PSP-toxins (e.g. the mussel, Mytilus edulis) readily feed on toxic cells (Bricelj et al. 1990) and thereby accumulate high toxin levels. In contrast, species that attain relatively low toxicities (e.g. the oyster, Crassostrea virginica), are highly sensitive to PSP-toxins and exhibit physiological and behavioural mechanisms to avoid or reduce exposure to toxic cells (Bricelj and Shumway 1998). However, there are some discrepancies between the in vitro assay of nerve sensitivity to STX or tetrodotoxin (TTX) and the whole-organism response to toxic cells. For example, the northern quahog, Mercenaria mercenaria, is insensitive to STX based on the in vitro assay, but was found to accumulate relatively low toxin levels during a major PSP outbreak (Twarog et al. 1972) and shows significant feeding inhibition and shell closure in the presence of a highly toxic Alexandrium isolate (Bricelj et al. 1991). In contrast, the surf-clam Spisula solidissima is highly sensitive to TTX, but shows no feeding or burrowing inhibition in response to dinoflagellate toxicities as high as $74 \mathrm{pg} \mathrm{STX} \mathrm{equiv.} \mathrm{cell}{ }^{-1}$ (Bricelj et al. 1996). Bricelj and Shumway (1998) showed that this surf-clam also achieved extremely high PSP toxicities in both field and laboratory studies, and suggested that the nerve assay must be verified using alternative in vivo measures of sensitivity such as physiological and behavioural responses. Clearance rates representing filtration ability provide a useful index to compare the toxin sensitivity and, thus, the potential for uptake by various species (Shumway and Cucci 1987). They can also be used to compare the response within a species to variations in dinoflagellate cell toxicity (Lee 1993; Bricelj et al. 1996).

Toxic algal blooms present not only a public health hazard, but also a major economic threat to aquaculture. The most effective means of controlling bivalve quality during outbreaks of toxic algae is either by a total closure during certain times of the year or by instituting a shellfish toxicity monitoring system. The latter approach has been carried out in many areas commonly plagued by such blooms (Shumway et al. 1988; Shumway 1990). Bivalve species differ in their ability to accumulate PSP-toxins (Fast et al. 2006) and such differences between co-occurring species are exploited in many monitoring programs (Shumway et al. 1988; Bricelj and Shumway 1998).

New Zealand shellfish have been monitored for the presence of marine biotoxins since January 1993 when shellfish toxicity was first detected in New Zealand (Mackenzie et al. 2004). Since 1993, New Zealand has implemented a very successful monitoring program, mainly based on cultivated mussels. However, the effects of paralytic shellfish poisoning (PSP) toxins on other species of bivalve molluscs are little known. As bivalve species exhibit a wide range of responses and sensitivities to PSP-toxins, it is necessary to investigate the effects of toxic dinoflagellates on the physiology of a diverse range of shellfish from New Zealand. 
The hypothesis tested in our study was that the feeding responses of bivalve species exposed to PSP-toxic dinoflagellates would be species-specific. To test this hypothesis, we measured the short-term exposure of five species of bivalve to the toxic dinoflagellate Alexandrium tamarense, using clearance rate as an indication of their sensitivity to PSP-toxins. The species chosen for this study were the green-lipped mussel Perna canaliculus, the surf clams Paphies donacina and Dosinia anus, the oyster Ostrea chilensis and the New Zealand scallop Pecten novaezelandiae. Control bivalves were fed with a non-toxic species, $A$. margalefi, which is similar in size to the toxic species. The total content of PSP-toxins in the bivalve tissues was measured at the end of the exposure period.

\section{Methods}

\section{Collection of the bivalve molluscs}

Fifty mussels, Perna canaliculus, (mean dry weight $\pm \mathrm{SD}=1.4 \pm 0.3 \mathrm{~g}$; mean shell length $\pm \mathrm{SD}$ $=72.8 \pm 3.0 \mathrm{~mm}$ ) were collected from subtidal culture ropes in Okains Bay, Banks Peninsula $\left(43^{\circ} 39^{\prime} 53^{\prime \prime} \mathrm{S}, 173^{\circ} 4^{\prime} 38^{\prime \prime} \mathrm{E}\right)$ in August 2007. Clams, Paphies donacina (mean dry weight $\pm \mathrm{SD}=3.8 \pm$ $0.8 \mathrm{~g}$; mean shell length $\pm \mathrm{SD}=86.2 \pm 3.6 \mathrm{~mm}$ ) and Dosinia anus (mean dry weight $\pm \mathrm{SD}=1.5 \pm$ $0.5 \mathrm{~g}$; mean shell length $\pm \mathrm{SD}=54.1 \pm 5.6 \mathrm{~mm}$ ) were collected at low tide by hand in the sand

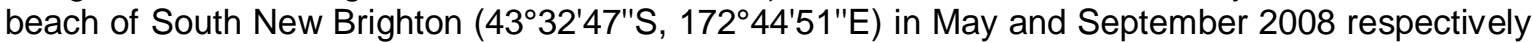
$(N=15$ of each species). Adults of both species of surf clams were collected in the same place. Scallops, Pecten novaezelandiae (mean dry weight $\pm \mathrm{SD}=3.6 \pm 0.8 \mathrm{~g}$; mean shell length $\pm \mathrm{SD}=$ $91.3 \pm 0.4 \mathrm{~mm}$ ) were collected in Ketu Bay, Marlborough Sounds (40 $\left.59^{\prime} 5 " \mathrm{~S}, 173^{\circ} 59^{\prime} 15^{\prime \prime} \mathrm{E}\right)$ by dredging in February $2009(N=125)$, and twenty oysters, Ostrea chilensis (mean dry weight \pm SD $=0.8 \pm 0.2 \mathrm{~g}$; mean shell length $\pm \mathrm{SD}=64.3 \pm 5.7 \mathrm{~mm}$ ) were collected from a floating wharf in

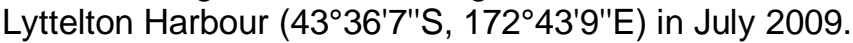

\section{Culture of microalgae}

Three microalgae were cultured for feeding the bivalve species. Tetraselmis suecica (CAWPR01) is a non-toxic green marine flagellate commonly used as a live food for bivalves, crustaceans and rotifers in hatcheries. Tetraselmis suecica was isolated from Brest in France in 1973 and cultured in a nutrient-enriched filtered seawater medium ( $\mathrm{f} / 2$; Guillard 1975) under 24-h continuous light at $19^{\circ} \mathrm{C}$ and with constant aeration in 10-L plastic bottles. The other two microalgae used in this study were the toxic dinoflagellate Alexandrium tamarense (CAWD121; diameter $=34 \mu \mathrm{m}$ ) and the non-toxic dinoflagellate Alexandrium margalefi (CAWD10; diameter = $40 \mu \mathrm{m}$ ). Both species of dinoflagellates have been isolated from Marsden Point in 1997 and 1993 respectively (Mackenzie et al. 2004). Alexandrium species were grown in a nutrient-enriched filtered seawater medium (GP: Loeblich and Smith 1968) under a 12-h light/dark cycle at $19^{\circ} \mathrm{C}$ and without aeration in 2-L flasks. The three species of microalgae were supplied by Cawthron Institute in Nelson, New Zealand.

\section{Experimental design}

Individuals of all bivalve species were acclimated to the laboratory conditions in circulating nonfiltered seawater aquaria (salinity of $30 ; 15^{\circ} \mathrm{C}$ ) and were daily fed ad libitum with Tetraselmis suecica for two weeks. The experimental protocols were the same for all species. Eight bivalves were chosen randomly from these aquaria and placed individually in experimental vessels containing seawater (salinity of $30 ; 15^{\circ} \mathrm{C}$ ) with constant aeration. Bivalves were fed with $T$. suecica for 4 days and the clearance rates measured on the last day. From the next day (day 0), four replicate individuals were exposed to the toxic dinoflagellate, Alexandrium tamarense (PSP group) and the other four replicates were fed with the non-toxic dinoflagellate, A. margalefi (control group), following the methodology described in Coughlan (1969) where a known quantity of algae (below the level of pseudofaeces production) was supplied to the bivalves (initial concentration, see Table 1). The decrease in algae in the water due to the filtration by the bivalves was determined using an 
AquaFluor $^{\mathrm{TM}}$ Handheld fluorometer (Turner Designers). Clearance rates were measured on the same individual from each replicate every 30 minutes for 2 hours.

Because of differences in body size and species clearance rates, the volume of sea water in the experimental vessels and the concentration of algae used for feeding the bivalves and measuring clearance rates differed among experiments (Table 1). Mussels, clams and scallops were exposed to the Alexandrium species for four days, whereas oysters were exposed for six days. This was because of the large variability of clearance rates measured until day 4. It was decided to expose oysters for another two days to provide a more reliable estimation of the clearance rate.

\section{Analysis of PSP-toxins in dinoflagellates and shellfish tissues}

\section{Extraction procedure}

After the last clearance rate measurement, the whole tissue of each bivalve was individually frozen at $-80^{\circ} \mathrm{C}$ for later quantification of PSP-toxins. Samples of tissues $(n=4$ per species of bivalve) and $A$. tamarense ( $n=3$ per experiment) were quantified by High Performance Liquid Chromatography (HPLC) with post-column oxidation. The extraction and quantification of PSPtoxins followed the procedure described in Rourke et al. (2008) with some modifications which are described below.

An aliquot of the culture was centrifuged at $2500 \mathrm{~g}$ for 15 minutes and the supernatant removed. The pellets were stored frozen at $-80^{\circ} \mathrm{C}$ until they were used in the extraction procedure. For the extraction, the pellets were defrosted and $500 \mu \mathrm{L}$ of $0.05 \mathrm{M}$ acetic acid $(\mathrm{AcOH})$ added. Cells were ruptured by sonication (on ice) using a micro-tip cell disrupter. Samples were then centrifuged and the supernatant (containing the toxins) transferred to ultrafiltration vials (10 $000 \mathrm{Da}$ molecular filter, Millipore Ultrafree-MC) and centrifuged again (14 $000 \mathrm{~g})$. The final filtrate was analysed by HPLC. The total amount of toxins in the dinoflagellates was given by the sum of all toxins quantified in the run and is expressed as pg STX-diHCl equiv. cell ${ }^{-1}$.

Tissue samples were defrosted and 0.1M hydrochloric acid $(\mathrm{HCl})$ was added in a 1:1 proportion and homogenised by Ultraturrax (on ice). Next, the $\mathrm{pH}$ of the homogenate was measured and adjusted to $\mathrm{pH} 3-4$, followed by centrifugation of the mixture. The supernatant was passed through a cartridge column (Sep-Pack C18, Waters) and then into an ultrafiltration vial (10 $000 \mathrm{Da}$ molecular filter, Millipore Ultrafree-MC). The last step is important for eliminating proteins. The final filtrate was analysed by HPLC. The total amount of toxins in the tissues of the bivalves was given by the sum of all toxins quantified in the run and is expressed as $\mu \mathrm{g} \mathrm{STX} \mathrm{di-HCl} \mathrm{equiv.} 100 \mathrm{~g}^{-1}$ of wet tissue.

\section{Quantification of toxins by HPLC}

A rapid liquid chromatography assay with post-column oxidation was used for quantificating PSP-toxins profiles following Rourke et al. (2008). The HPLC system involved two separate runs using a different column for each run: one for C1-C2 toxins and the other for GTX1-5, dcGTX2-3, $\mathrm{Neo}$, dcNeo, STX and dcSTX toxins. C toxins were eluted from a column Phenomenex Synergy $4 \mu$ Hydro RP-80A 250 x 4.6 using tetrabutyl ammonium phosphate (pH 5.8) for 10 minutes. GTX/STX toxins were eluted using a programmed gradient of four mobile phases over 40 minutes on a column Phenomenex Synergy $4 \mu$ Polar RP-80A $250 \times$ 4.6. The mobile phases included acetonitrile, ammonium phosphate ( $\mathrm{pH}$ 6.9), sodium heptanesulphonic acid and Milli-Q water. The system was calibrated using the following standards from The Certificated References Materials Program (CRMP) operated by the National Research Council of Canada (NRC); C1, C2, dcGTX2, dcGTX3, dcSTX, dcNeo, GTX1, GTX2, GTX3, GTX4, GTX5, Neo and STX.

Unfortunately, separation of dcGTX3 and GTX5 toxins was not consistent during the trial runs, and it was decided to express them as a combination of the two toxins eluting at 10.6 minutes (dcGTX3 + GTX5). The same situation occurred with dcNEO and Neo and they were also expressed in the toxin profile as a combination that had eluted at 22.9 minutes (dcNeo $+\mathrm{Neo}$ ). Due to the separation problem, the relative toxicity of these combinations was not possible to determine. Therefore, dcGTX3 + GTX5 was calculated using the relative toxicity of dcGTX3 (0.3766) and 
dcNeo + Neo was calculated using the relative toxicity of Neo (0.9243). For quantification calculations, we used the relative toxicity of PSP-toxins presented in Cembella et al. 1993.

\section{Statistical analyses and standardisation of the data}

Because the physiological responses were measured on the same individual over a period of time, the results were compared using repeated measures ANOVA to test the effects of the different treatments (within tests $=$ PSP and control group) and the effect of exposure time on the response of the bivalve species (between tests $=$ days). Data were first examined for homogeneity of variances (Levene's test) and normality (Kolmogorov-Smirnov test). Where the data did not conform to normality or homoscedacity, they were transformed, either by natural log or square root. When there were significant differences within or between means, a post-hoc Tukey multiple comparison test was performed (Snedecor and Cochran 1989). All analyses were done using STATISTICA 8.

The dry weight of the bivalves was needed for the physiological and behavioural responses to correct for the effects of body size. Wet tissues were weighed for the control group, then dried for $72 \mathrm{~h}$ at $60^{\circ} \mathrm{C}$ and re-weighed. The dry weight of the PSP group could not be measured directly and was estimated using the wet/dry weight ratio of the control group which was constant for each species (data not included).

The influence of body size on clearance rates has been widely reviewed i (Jørgensen 1976; Winter 1978; Newell 1979); filtration rate (y) increases allometrically with increasing body size $(x)$ as $y=a x^{b}$. The value of 0.75 represents an approximate mean of $b$ for a variety of bivalve species (Jørgensen 1976; Widdows 1978; Winter 1978) and was used in this study to correct the results to a standard-sized organism of $1 \mathrm{~g}$ dry weight.

\section{Results}

\section{Effects of $A$. tamarense on clearance rate}

The clearance rate of mussels was unaffected by the dinoflagellate species supplied in the diet (Fig. 1a). Overall, the clearance rate of mussels fed on Tetraselmis suecica was $1.29 \mathrm{~L} \mathrm{~h}^{-1} \mathrm{~g}^{-1}$ (PSP and control groups). When the diet was changed to Alexandrium species, there was no change in the clearance rate. In the clam Paphies donacina, rates decreased in the presence of dinoflagellates, both for PSP and control groups (Fig. 1b). At the beginning of the experiment, the feeding rates of both groups fed with Tetraselmis suecica was $0.13 \mathrm{~L} \mathrm{~h}^{-1} \mathrm{~g}^{-1}$. However, when the diet was changed to Alexandrium species (toxic and non toxic), both groups decreased feeding rate to $0.06 \mathrm{~L} \mathrm{~h}^{-1} \mathrm{~g}^{-1}$. Low clearance rates were observed over the next four days without significant differences between the PSP and control groups $\left(F_{1,6}=0.58, P=0.47\right)$.

The clearance rate of the clam, Dosinia anus was also unaffected by the presence of dinoflagellate species supplied in the diet (Fig. 1c). Both groups supplied with Tetraselmis suecica had a clearance rate close to $0.22 \mathrm{~L} \mathrm{~h}^{-1} \mathrm{~g}^{-1}$, which was similar to the clearance rate observed on days 0,2 and 4 when the clams had been feeding on the Alexandrium species $\left(0.23 \mathrm{~L} \mathrm{~h}^{-1} \mathrm{~g}^{-1}\right.$ for both groups).

The clearance rate of scallops Pecten novaezelandiae fed with the toxic dinoflagellate decreased in the presence of PSP-toxins. At the beginning of the experiment, the PSP and control groups fed with Tetraselmis suecica had similar clearance rates $\left(0.77 \mathrm{~L} \mathrm{~h}^{-1} \mathrm{~g}^{-1}\right)$ but when the food supply was changed (day 0 ), the PSP group exposed to the toxic dinoflagellates decreased its clearance rate (Fig. 1d). On the same day, the control group fed with the non-toxic dinoflagellate $A$. margalefi had a rate similar to that observed for $T$. suecica. Over the four days of exposure to the toxic and non-toxic dinoflagellates, clearance rates differed between the PSP and control groups $\left(F_{1,6}=120.78, P<0.001\right)$.

The clearance rates of the PSP-exposed and control oysters were highly variable over the experiment (Fig. 1e). Similar values $\left(0.15 \mathrm{~L} \mathrm{~h}^{-1} \mathrm{~g}^{-1}\right)$ were found for both groups in the pre-feeding 
trial when fed with Tetraselmis suecica. There were no significant differences in clearance rate between the PSP and the control groups $\left(F_{1,6}=0.05, P=0.82\right)$. However, time had a significant effect $\left(F_{4,24}=8.97, P<0.001\right)$ on this physiological response, confirming the variability of the behaviour of oysters.

\section{PSP-toxin profile of Alexandrium tamarense and in the tissues of the bivalves}

The toxin profile of the dietary dinoflagellate species $A$. tamarense was dominated by the $\mathrm{N}$ sulfocarbamoyl toxin, C2 (91.5\%). The other toxins identified were dcSTX (5.3\%) and GTX4 (1.2\%), accompanied by trace amounts of dcNeo + Neo, STX, dcGTX3 + GTX5, C1, GTX1 and GTX3. Although the total toxin content was $353 \pm 97 \mathrm{fmol} \mathrm{cell}^{-1}$, the predominance of $\mathrm{C} 2$ resulted in a cell-specific toxicity of $35 \pm 9$ fmol STX-diHCl equiv. cell ${ }^{-1}$ or $16 \pm 4 \mathrm{pg} \mathrm{STX}$-diHCl equiv. cell $^{-1}$.

The toxin profile of Perna canaliculus was dominated by the carbamoyl toxin, GTX1 (72\%) and $\mathrm{N}$-sulfocarbamoyl toxin, C2 (19\%). The compound GTX2 was detected in the tissues of mussels but not in the toxin profile of the dinoflagellate. Mussels had accumulated $88 \mu \mathrm{g} \mathrm{STX} \mathrm{di-HCl} \mathrm{equiv.}$ $100 \mathrm{~g}^{-1}$ after four days of feeding on A. tamarense. The toxin profile of the clam Paphies donacina was dominated by dcGTX3 + GTX5 (47\%) and the decarbamoyl toxin, dcGTX2 was found in the clams $(10 \%)$ but was not detected in the toxin profile of the dinoflagellate. The tissues of $P$. donacina had accumulated $28 \mu \mathrm{g}$ STX di-HCl equiv. $100 \mathrm{~g}^{-1}$ after four days of exposure to $A$. tamarense. The clam Dosinia anus had a toxin profile dominated by the carbamoyl toxin, GTX1 (48\%) and the $\mathrm{N}$-sulfocarbamoyl, C2 (37\%) and had accumulated $59 \mu \mathrm{g}$ STX di-HCl equiv. $100 \mathrm{~g}^{-1}$ after 4 days of exposure to $A$. tamarense. The toxin profile of Pecten novaezelandiae was dominated by the $\mathrm{N}$-sulfocarbamoyl, C2 (60\%) and GTX2 was detected in the scallops but was not observed in the dinoflagellate. Scallops had accumulated $30 \mu \mathrm{g} \mathrm{STX}$ di-HCl equiv. $100 \mathrm{~g}^{-1}$ after four days of exposure to $A$. tamarense. The toxin profile of Ostrea chilensis was dominated by the $\mathrm{N}$ sulfocarbamoyl, C2 (49\%). Oysters had accumulated $46 \mu \mathrm{g} \mathrm{STX}$ di-HCl equiv. $100 \mathrm{~g}^{-1}$ of tissue after six days of exposure to $A$. tamarense (Table 2).

\section{Discussion}

The five species of New Zealand bivalves tested in this study differed in clearance rates when exposed to dinoflagellates containing PSP-toxins. These findings agree with those from other bivalve species from different latitudes (Shumway and Cucci 1987; Lassus et al. 1989; Bricelj et al. 1991). These responses show that filter-feeding bivalve molluscs vary widely in their capacity to ingest toxic dinoflagellates.

\section{Species-specific effects of PSP-toxins on the clearance rates of bivalve species}

\section{Mussels}

In the present study, the New Zealand mussel, Perna canaliculus appeared to feed normally on both toxic and non-toxic dinoflagellate cells, as reported by Marsden and Shumway (1992) who also observed that $P$. canaliculus showed no dramatic physiological effects following short-term feeding on A. tamarense. In general, mussels (e.g. Mytilus edulis) are tolerant to PSP-toxins and they readily feed on toxic cells. Also, a high PSP-toxin level is found in their tissues (Bricelj et al. 1990). In the Chilean mussel Mytilus chilensis, bivalves were initially affected by the toxic dinoflagellate $A$. catenella and had a lower clearance rate than control mussels fed with the nontoxic microalgae Isochrysis galbana. After a few days of exposure to the toxic dinoflagellate, $M$. chilensis recovered its feeding rate to pre-exposure levels, accumulating high levels of PSP-toxins in the tissues (Navarro and Contreras 2010; Navarro et al. 2011). 
Clams

The clams Paphies donacina and Dosinia anus presented different responses to dinoflagellates, illustrating a clear species-specific effect on co-occurring species of clams. The clearance rates of $P$. donacina fed on toxic and non-toxic Alexandrium species were significantly lower than the rates observed when fed on Tetraselmis suecica. Although a clear effect from the Alexandrium species was observed on the clearance rate of $P$. donacina, it was not possible to conclude whether the PSP-toxins resulted in any physiological response. It is possible that either the PSP-toxins did not affect the clearance rate of $P$. donacina or the effect of the PSP-toxins was masked by the effect of the Alexandrium cells. Further, the toxicity of $A$. tamarense used for feeding the bivalves (16 pg STX-diHCl cell ${ }^{-1}$ ) may have been too low to inhibit the feeding rate of this clam, as observed in the clam Mya arenaria (Bricelj et al. 1996). These authors indicated that a significant reduction in the clearance rate of $M$. arenaria occurred only when clams were fed on the highly toxic Alexandrium tamarense (as A. excavatum PR18b) (74.5 pg STX equiv. cell ${ }^{-1}$ ), but not on other, less toxic species.

In contrast, other species of clams such as Spisula solidissima appear insensitive to the effects of PSP-toxins and can attain high toxicities of PSP-toxins in their tissues (Shumway et al. 1994; Silvert et al. 1998). In our study, the clearance rate of the clam Dosinia anus was insensitive to PSP-toxins and to the effect of Alexandrium species. The results from $P$. donacina and $D$. anus from New Zealand confirm that species that coexist in the same habitat can have different responses when exposed to toxic dinoflagellate cells.

\section{Scallops}

Pecten novaezelandiae was significantly affected by toxic dinoflagellates in the diet. Scallops reduced their clearance rate significantly from the first contact with Alexandrium tamarense cells until the end of the experiment. Control scallops fed normally on non-toxic dinoflagellate cells, confirming the effects of PSP-toxins on the clearance rate of the bivalve. It has been reported in the literature that scallops are sensitive to PSP-producing dinoflagellates. Juveniles of the giant lionspaw scallop, Nodipecten subnodasus showed a decreased clearance rate when exposed to Gymnodinium catenatum at concentrations greater than 450 cell mL ${ }^{-1}$ (Estrada et al. 2007). Shumway and Cucci (1987) observed that although Pecten magellanicus exposed to $A$. tamarense (as Protogongaulax tamarensis) fed normally, they also showed striking behavioural responses, immediately closing their valves followed by either violent swimming activity, partial sustained shellvalve closure, or a combination of the two. On addition of clear sea water, this activity ceased.

\section{Oysters}

In the present study, as in others (Shumway et al. 1990; Luckenbach et al. 1993; Lassus et al. 1996), there was a high individual and daily variation in physiological responses in oysters. Shumway and Cucci (1987) found that the clearance rate of Crassostrea virginica was significantly inhibited by addition of toxic cells, whereas that in Ostrea edulis was stimulated. Furthermore, in Maine waters, $O$. edulis became toxic several days prior to any other species, including the mussel, Mytilus edulis (Shumway et al. 1988). Tran et al. (2010) recorded valve activity of Crassostrea gigas, exposed to $A$. minutum, using avalvometer equipped with electromagnetic electrodes. They found that $C$. gigas remained open longer, the amplitude of valve opening was reduced, and the number of micro-closures increased when exposed to A. minutum. Ostrea chilensis from New Zealand did not respond clearly to any of the variables tested over the experiment, possibly due to the low number of replicates. Oysters increased and decreased clearance rates over the six days of exposure to Alexandrium species, showing an erratic response over the time which may be unrelated to PSP-toxins. The results were not conclusive and further studies are needed, including a higher number of replicates and a longer period of exposure to toxic and non-toxic dinoflagellate cells. 


\section{Accumulation and transformation of PSP-toxins in the tissues of the bivalve}

The species-specific differences in the clearance rate recorded in the present study were also reflected in the total content of toxins in the tissues. The scallop $P$. novaezelandiae and the clam $P$. donacina decreased their clearance rates in the presence of Alexandrium species and also accumulated fewer toxins in their tissues than the most resistant bivalves $(P$. canaliculus and $D$. anus). Oysters accumulated more toxins than $P$. novaezelandiae and $P$. donacina, but they were exposed to two more days of exposure to $A$. tamarense; therefore, they may have a similar intoxication response as the other bivalve species. The rate of accumulation of PSP-toxins in the tissues of marine bivalves is influenced not only by their feeding behaviour (rate of intake of PSPtoxins), but also by the different chemical processes that take place in the tissues of the bivalve. In this study, all bivalves were supplied with the same toxic dinoflagellate but each species presented different biotransformation processes of PSP-toxins.

We found differences between the toxin composition in ingested dinoflagellates and in bivalve tissues. These may arise from epimerisation of the ingested toxins, chemical or enzymatic transformations, and/or selective retention of the individual toxins. These differences are greatest when dinoflagellate strains are rich in the low-potency but highly labile $N$-sulfocarbamoyl toxins (Bricelj et al. 1991). Epimerisation from the $\beta$-epimers to $\alpha$-epimers in the tissues of mussels has been widely reported (Bricelj et al. 1990; Oshima et al. 1990; Oshima 1995; Ichimi et al. 2001) and corroborates the results obtained for the New Zealand mussel Perna canaliculus that contained high levels of GTX1. The $\beta$-epimers (C2, C4, GTX3, GTX4) are the favoured configuration in dinoflagellates and the $\alpha$-epimers (C1, C3, GTX2, GTX1) will gradually convert to the more stable $\alpha$ configuration in the shellfish tissues under thermodynamic equilibration conditions (Oshima 1995). The toxin profile of Dosinia anus was similar to that observed in the mussel Perna canaliculus where an active epimerisation of the $\beta$-epimers to $\alpha$-epimers had taken place, leading to the production of high quantities of GTX1.

In contrast with the above results, a few clam species are capable of enzymatic production of decarbamoyl toxins from $\mathrm{N}$-sulfocarbamoyl and, in some cases, carbamate derivatives: Spisula solidissima (Cembella et al. 1993; Bricelj et al. 1996), Protothaca staminea (Sullivan et al. 1983) and Mactra chinensis and Peronidia venulosa (Oshima 1995). In our study, Paphies donacina presented high quantities of dcGTX3 + GTX5 and dcGTX2 in the tissues. Unfortunately, it was not possible to quantify dcGTX3 separately. However, due to the high capacity of enzymatic production of decarbamoyl toxins from $\mathrm{N}$-sulfocarbamoyl observed in some other species of clams, it is likely that $P$. donacina from New Zealand has the same capacity for bioconversion. Mackenzie et al. (1996) observed that in tissues of Paphies subtriangulata from the Bay of Plenty, North Island of New Zealand, there were high concentrations of STX and neoSTX. This same feature was observed in our study on $P$. donacina from the South Island.

Different toxin profiles occurred in the two co-existing clams from New Zealand. Paphies donacina presented high amounts of decarbamoyl derivates whereas the toxin profile of Dosinia anus was dominated by the carbamoyl derivate GTX1. These findings agree with those of Fast et al. (2006) who found extreme differences between the toxin profile of the Pacific littleneck Protothaca staminea and the softshell Mya arenaria in their capacity for PSP toxin transformation. The littleneck clam showed a remarkable conversion of $\mathrm{N}$-sulfocarbamoyl toxins to decarbamoyl derivatives whereas the softshell clam showed an increased concentrations in both GTX2 and GTX1 following incubation with GTX2/GTX3 epimers.

Ostrea chilensis and Pecten novaezelandiae presented the lowest bioconversion rates of PSPtoxins amongst the five species of New Zealand bivalves analysed in this study. The toxin profile of both species contained high quantities of the $\mathrm{N}$-sulfocarbamoyl, $\mathrm{C} 2$ which was also dominant in the toxin profile of Alexandrium tamarense. GTX1 and GTX2 also occurred in the toxin profiles of oysters and scallops, but in lesser proportions than in clams and mussels. Lassus et al. (2007) observed that the oyster Crassostrea gigas fed on Alexandrium catenella presented toxin profiles that were only slightly different or the same as the toxin profile of the toxic dinoflagellate. In both toxin profiles, the $\mathrm{N}$-sulfocarbamoyl $\mathrm{C} 2$ was the major toxin found. These results are similar to the toxin profile of Ostrea chilensis from New Zealand. The toxin profile of the scallop, $P$. novaezelendiae also presented high quantities of $\mathrm{C} 2$, indicating low bioconversion of PSP-toxins in scallops. Cembella et al. (1994) studied the seasonal variation of the toxin profile of the scallop Placopecten magellanicus exposed to $A$. tamarense. They found that the sea scallops exposed to PSP-toxins contained high amounts of $\mathrm{N}$-sulfocarbamoyl toxins which represented a large reservoir 
of potential toxicity. They also suggested that the high proportion of this toxin in the tissues of scallops indicated recent exposure to toxic dinoflagellates which is in agreement with the results observed in P. novaezelandiae exposed to A. tamarense.

\section{Conclusions}

The differences in the clearance rate responses among the five bivalve species from New Zealand studied here and the levels of PSP-toxins accumulated in their tissues are important when selecting species for aquaculture in areas prone to toxic algal blooms. Species that rapidly achieve elevated toxin levels in the presence of PSP-toxins, such as Perna canaliculus, are ideal indicator organisms to provide early warning of PSP outbreaks. This research therefore supports the use of mussels as the sentinel animal for monitoring programs in New Zealand and worldwide.

Our research also confirmed that clams, scallops and oysters respond differently when exposed to toxic dinoflagellates. This highlights the need for further research on a wide range of bivalve species from New Zealand. It is also important to understand the rates at which toxins are eliminated from bivalve after exposure to a bloom. We recommend that the toxin levels in a range of bivalve species exposed to natural PSP blooms be measured in future monitoring studies. This information will allow better management of shellfish that are exposed to PSP causing toxic dinoflagellate blooms.

\section{Acknowledgments}

We thank Lincoln Mackenzie and Veronica Beuzenberg from Cawthron Institute, Nelson for initial training and advice in the setting up the HPLC for the PSP-toxin analyses in the Chemistry Department, University of Canterbury. Rennie Bishop, Jan Mckenzie and Gavin Robinson from the School of Biological Sciences helped with the collection of shellfish and setting up the experiments. We thank two anonymous referees for valuable comments on this paper and the University of Canterbury for the award of a doctoral scholarship to A.M. Contreras. Bivalves were collected under permit from the New Zealand Ministry of Fisheries.

\section{References}

Basti, L., Nagai, K., Shimasaki, Y., Oshima, Y., Honjo, T., and Segawa, S. (2009). Effects of the toxic dinoflagellate Heterocapsa circularisquama on the valve movement behaviour of the Manila clam Ruditapes philippinarum. Aquaculture 291, 41-47.

Bricelj, V., and Shumway, S. (1998). Paralytic shellfish toxins in bivalve molluscs: Occurrence, transfer kinetics, and biotransformation. Reviews in Fisheries Sciences 6, 315-383.

Bricelj, V., Lee, J., Cembella, A., and Anderson, D. (1990). Uptake kinetics of paralytic shellfish toxins from the dinoflagellate Alexandrium fundyense in the mussel Mytilus edulis. Marine Ecology Progress Series 63, 177-188.

Bricelj, V., Lee, J., and Cembella, A. (1991). Influence of dinoflagellate cell toxicity on uptake and loss of paralytic shellfish toxins in the northern quahog, Mercenaria mercenaria. Marine Ecology Progress Series 74, 33-46.

Bricelj, V., Cembella, A., Laby, D., Shumway, S., and Cucci, T. (1996). Comparative physiological and behavioral responses to PSP toxins in two bivalve molluscs, the softshell clam, Mya arenaria, and surfclam Spisula solidissima. In 'Harmful and Toxic Algal Blooms'. (Eds T. Yasumoto, Y. Oshima and Y. Fukuyo.) pp. 405-408. (UNESCO: Japan.)

Bricelj, V., Ford, S., Lambert, C., Barbou, A., and Paillard, C. (2011). Effects of toxic Alexandrium tamarense on behavior, hemocyte responses and development of brown ring disease in Manila clams. Marine Ecology Progress Series 430, 35-48. 
Cembella, A., Shumway, S., and Lewis, N. (1993). Anatomical distribution and spatio-temporal variation in paralytic shellfish toxin composition in two bivalve species from the Gulf of Maine. Journal of Shellfish Research 12, 389-403.

Cembella, A., Shumway, S., and Larocque, R. (1994). Sequestering and putative biotransformation of paralytic shellfish toxins by the sea scallop Placopecten magellanicus: seasonal and spatial scales in natural populations. Journal of Experimental Marine Biology and Ecology 180, 1-22.

Coughlan, J. (1969). The estimation of filtering rate from the clearance of suspensions. Marine Biology 2, 356-358.

Elke, J., Gunnar, G., and Bernd, L. (2007). In vitro transformation of PSP toxins by different shellfish tissue. Harmful Algae 6, 308-316.

Estrada, N., Lagos, N., Garcia, C., Maeda-Martinez, A., and Ascencio, F. (2007). Effects of the toxic dinoflagellate Gymnodinium catenatum on uptake and fate of paralytic shellfish poisons in the Pacific giant lions-paw scallop Nodipecten subnodosus. Marine Biology 4, 1205-1214.

Fast, M., Cembella, A., and Ross, N. (2006). In vitro transformation of paralytic shellfish toxins in the clams Mya arenaria and Protothaca staminea. Harmful Algae 5, 79-90.

Guillard, R. (1975). Culture of phytoplankton for feeding marine invertebrates. In 'Culture of Marine Invertebrate Animals'. (Eds W. Smith, and M. Chanley.) pp. 29-60. (Plenum Press: New York.)

Haberkorn H., Tran D., Massabuau J. C., Ciret P., Savar V., and Soudant P. (2011) Relationship between valve activity, microalgae concentration in the water and toxin accumulation in the digestive gland of the Pacific oyster Crassostrea gigas exposed to Alexandrium minutum. Marine Pollution Bulletin 62, 1191-1197.

Hallegraeff, G. (1993). A review of harmful algae blooms and their apparent global increase. Phycologia 32, 79-99.

Ichimi, K., Suzuki, T., and Yamasaki, M. (2001). Non-selective retention of PSP toxins by the mussel Mytilus galloprovincialis fed with the toxic dinoflagellate Alexandrium tamarense. Toxicon 39, 1917-1921.

Jørgensen, C. (1976). Growth efficiencies and factors controlling size in some mytilid bivalves, especially Mytilus edulis L.: a review and interpretation. Ophelia 15, 175-192.

Kvitek, R., and Beitler, M. (1991). Relative insensitivity of butter clam neurons to saxitoxin: a pre-adaption for sequestering paralytic shellfish poisoning toxins as a chemical defense. Marine Ecology Progress Series 69, 47-54.

Lassus, P., Fremy, J., Ledoux, M., Bardouil, M., and Bohec, M. (1989). Patterns of experimental contamination by Protogonyaulax tamarensis in some French commercial shellfish. Toxicon 27 , 1313-1321.

Lassus, P., Wildish, D., Bardouil, M., Martin, J., Bohec, M., and Bougrier, S. (1996). Echophysiological study of toxic Alexandrium spp. effects on the oyster Crassostrea gigas. In 'Harmful and Toxic Algal Blooms' (Eds T. Yasumoto, Y. Oshima and Y. Fukuyo.) pp. 409-412. (UNESCO: Japan.)

Lassus, P., Amzil, Z., Baron, R., Séchet, V., Barillé, L., Abadie, E., Bardouil, M., Sibat, M., Truquet, P., Bereard, J., and Guéguen, M. (2007). Modelling the accumulation of PSP toxins in Thau Lagoon oysters (Crassostrea gigas) from trials using mixed cultures of Alexandrium catenella and Thalassiosira weissflogii. Aquatic Living Resources 20, 59-67.

Lee, J. (1993). The kinetics of PSP toxin transfer from the toxic dinoflagellate, Alexandrium spp. to two bivalve mollusc species, Mytilus edulis and Mercenaria mercenaria. Masters thesis, University of New York, New York.

Loeblich, A. R., and Smith, V. E. (1968). Chloroplast pigments of the marine dinoflagellate Gyrodinium resplendens. Lipids 3, 5-13.

Luckenbach, M., Sellner, K.G., Shumway, S.E., and Greene, K. (1993). Effects of two bloomforming dinoflagellates, Prorocentrum minimum and Gyrodinium uncatenum, on the growth and 
survival of the eastern oyster, Crassostrea virginica (Gmelin 1791). Journal of Shellfish Research $12,411-415$.

Mackenzie, L., White, D., and Adamson, J. (1996). Temporal variation and tissue localization of paralytic shellfish toxins in the New Zealand tuatua (surfclam), Paphies subtriangulata. Journal of Shellfish Research 15, 735-740.

Mackenzie, L., de Salas, M., Adamson, J., and Beuzenberg, V. (2004). The dinoflagellate genus Alexandrium (Halim) in New Zealand coastal waters: comparative morphology, toxicity and molecular genetics. Harmful Algae 3, 71-92.

Marsden, I., and Shumway, S. (1992). Effects of the toxic dinoflagellate Alexandrium tamarense on the greenshell mussel Perna canaliculus. New Zealand Journal of Marine and Freshwater Research 26, 371-378.

Nagai, K., Honjo, T., Go, J., Yamashita, H., and Oh, S. J. (2006). Detecting the shellfish killer Heterocapsa circularisquama (Dinophyceae) by measuring bivalve valve activity with a Hall element sensor. Aquaculture 255, 395-401.

Navarro, J., and Contreras, A. (2010). An integrative response by Mytilus chilensis to the toxic dinofagellate Alexandrium catenella. Marine Biology 157, 1967-1974.

Navarro, J., Aguila, B., Machmar , F., Chaparro, O., and Contreras, A. (2011). Dynamic of intoxication and detoxification in juveniles of Mytilus chilensis (Bivalvia: Mytilidae) exposed to paralytic shellfish toxins. Aquatic Living Resources 24: 93-98.

Newell, R. I. E. (1979). 'Biology of Intertidal Animals.' (Marine Ecological Surveys Ltd: Faversham, Kent.)

Oshima, Y. (1995). Chemical and enzymatic transformation of paralytic shellfish toxins in marine organisms. In 'Harmful Marine Algal Blooms: Proceedings of the Sixth International Conference on Toxic Marine Phytoplankton'. (Ed P. Lassus.) pp. 475-480 (Lavoisier: Nantes.)

Oshima, Y., Sugino, K., Itakura, H., Hirota, M., and Yasumoto, T. (1990). Comparative studies on paralytic shellfish toxin profile of dinoflagellates and bivalves. In 'Toxic Marine Phytoplankton'. (Eds E. Granéli, B. Sundström, L. Edler, and D. Anderson.) pp. 391-396 (Elsevier: New York.)

Rodríguez Rodríguez, G., Villasante, S., and García Negro, M. (2011). Are red tides affecting economically the commercialization of the Galician (NW Spain) mussel farming? Marine Policy 35, 252-257.

Rourke, W. A., Murphy, C. J., Pitcher, G., Van De Riet, J. M, Burns, B. G., Thomas, K. M., and Quilliam, M. A. (2008). Rapid postcolumn methodology for determination of paralytic shellfish toxins in shellfish tissue. Journal of AOAC International 91, 589-597.

Shumway, S., and Cucci, T. (1987). The effects of the toxic dinoflagellate Protogonyaulax tamarensis on the feeding and behaviour of bivalve molluscs. Aquatic Toxicology 10, 9-27.

Shumway, S., Cucci, T., Newell, R., and Yentsch, C (1985). Particle selection, ingestion and absorption in filter feeding bivalves. Journal of Experimental Marine Biology and Ecology 91, 7792.

Shumway, S., Sherman-Caswell, S., and Hurst, J. (1988). Paralytic shellfish poisoning in Maine: monitoring a monster. Journal of Shellfish Research 7, 643-652.

Shumway, S., Barter, J., and Sherman-Caswell, S. (1990). Auditing the impact of toxic algal blooms in oysters. Environmental Auditor 2, 41-56.

Shumway, S., Sherman, S., Cembella, A., and Selvin, R. (1994). Accumulation of paralytic shellfish toxins by surfclams, Spisula solidissima (Dillwyn, 1987) in the Gulf of Maine: seasonal changes, distribution between tissues, and notes on feeding habits. Natural toxins 2, 236-251.

Silvert, W., Bricelj, V., and Cembella, A. (1998). Dynamic modelling of PSP toxicity in the surfclam (Spisula solidissima): multicompartmental kinetics and biotransformation. In 'Harmful Algae'. (Eds B. Reguera, J. Blanco, M. Fernández and T. Wyatt.) pp. 437-440. (Xunta de Galicia and UNESCO: Spain.)

Snedecor, G. W., and Cochran, W. G. (1989). 'Statistical Methods.' 8th edn. (Blackwell: lowa) 
Sullivan, J., Iwaoka, W., and Liston, J. (1983). Enzymatic transformation of PSP toxins in the littleneck clam (Protothaca staminea). Biochemical and Biophysical Research Communications $114,465-472$.

Tran, D., Haberkorn, H., Soudant, P., Ciret, P., and Massabuau, J. C. (2010). Behavioral responses of Crassostrea gigas exposed to the harmful algae Alexandrium minutum. Aquaculture 298, 338-345.

Twarog, B., Hidaka, T., and Yamaguchi, H. (1972). Resistance to tetrodotoxin and saxitoxin in nerves of bivalve molluscs. Toxicon 10, 273-278.

Widdows, J. (1978). Combined effects of body size, food concentration and season on the physiology of Mytilus edulis. Journal of the Marine Biology Association of the United Kingdom 58, 109-124.

Winter, J. E. (1978). A review of the knowledge of suspension-feeding in lamellibranchiate bivalves, with especial reference to artificial aquaculture systems. Aquaculture 13, 1-33. 
Table 1: Summary of the composition of the diets supplied to five bivalve species during the experiments. (1) The feeding diets correspond to the daily concentration of algae supplied to the bivalve. (2) The clearance rate diets correspond to the initial concentration of algae used for measuring the clearance rate.

\section{P. canaliculus $\quad P$. donacina $\quad D$. anus}

$P$.

O. chilensis

novaezelandiae

\section{Feeding diets}

\begin{tabular}{|c|c|c|c|c|c|}
\hline 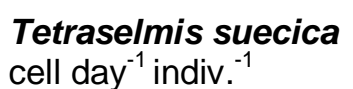 & $5 \times 10^{7}$ & $2.5 \times 10^{7}$ & $2.5 \times 10^{\prime}$ & $2.5 \times 10^{7}$ & $2.5 \times 10$ \\
\hline \multirow{2}{*}{\multicolumn{6}{|c|}{$\begin{array}{l}\text { A. tamarense } \\
\text { nmol STX equiv. day }\end{array}$}} \\
\hline & 350 & & 175 & 350 & \\
\hline cell day ${ }^{-1}$ indiv. $^{-1}$ & $10^{6}$ & $5 \times 10^{5}$ & $5 \times 10^{5}$ & $10^{6}$ & $5 \times 10^{5}$ \\
\hline $\begin{array}{l}\text { A. margalefi } \\
\text { cell day }^{-1} \text { indiv. } \\
\text { Volume vessel }^{-1}\end{array}$ & $10^{6}$ & $5 \times 10^{5}$ & $5 \times 10^{5}$ & $10^{6}$ & $5 \times 10^{5}$ \\
\hline Liters & 2 & 2 & 1 & 4 & 2 \\
\hline
\end{tabular}

\section{(2) Clearance rate diets}

\begin{tabular}{|c|c|c|c|c|c|}
\hline $\begin{array}{l}\text { Tetraselmis suecica } \\
\text { cell day }^{-1} \text { indiv. }^{-1}\end{array}$ & $10 \times 10^{6}$ & $5 \times 10^{6}$ & $5 \times 10^{6}$ & $5 \times 10^{6}$ & $5 \times 10^{6}$ \\
\hline $\begin{array}{l}\text { A. tamarense } \\
\text { nmol STX equiv dav }\end{array}$ & & 0 & 9 & 18 & 9 \\
\hline cell day ${ }^{-1}$ indiv. $^{-1}$ & $5 \times 10^{5}$ & $2.5 \times 10^{5}$ & $2.5 \times 10^{5}$ & $5 \times 10^{5}$ & $2.5 \times 10^{5}$ \\
\hline $\begin{array}{l}\text { A. margalefi } \\
\text { cell day }^{-1} \text { indiv. } \\
\text { Volume vessel }^{-1}\end{array}$ & $5 \times 10^{5}$ & $2.5 \times 10^{5}$ & $2.5 \times 10^{5}$ & $5 \times 10^{5}$ & $2.5 \times 10^{5}$ \\
\hline Liters & 2 & 1 & 0.8 & 2 & 0.5 \\
\hline
\end{tabular}


Table 2: PSP toxin profiles of mussels ( $P$. canaliculus), clams ( $P$. donacina, $D$. anus), scallops ( $P$. novaezelandiae), and oysters $(O$. chilensis) fed with the dinoflagellate $A$. tamarense. Values are expressed in $\mu \mathrm{g} \mathrm{STX} \mathrm{di-HCl} \mathrm{equiv.} 100 \mathrm{~g}^{-1}(\mathrm{~T})$ and as a proportion of the total content of toxins in this tissue (\%). The compound dominating the toxin profiles of each bivalve is shown in bold.

\begin{tabular}{|c|c|c|c|c|c|c|c|c|c|c|}
\hline & \multicolumn{2}{|c|}{ P. canaliculus } & \multicolumn{2}{|c|}{ P. donacina } & \multicolumn{2}{|c|}{ D. anus } & \multicolumn{2}{|c|}{ P. novaezelandiae } & \multicolumn{2}{|c|}{ O. chilensis } \\
\hline & $\mathrm{T}$ & $\%$ & $\mathrm{~T}$ & $\%$ & $\mathrm{~T}$ & $\%$ & $\mathrm{~T}$ & $\%$ & $\mathrm{~T}$ & $\%$ \\
\hline GTX4 & 3.1 & 3.6 & 1.1 & 3.8 & 3.3 & 5.6 & 3.2 & 10.7 & 5.0 & 10.8 \\
\hline GTX1 & 63.1 & 71.8 & 3.5 & 12.7 & 28.2 & 48.1 & 5.5 & 18.6 & 9.6 & 20.7 \\
\hline dcGTX3 & +1.3 & 1.5 & 13.0 & 47.3 & 1.0 & 1.7 & 0.9 & 2.9 & 1.7 & 3.8 \\
\hline GTX5 & & & & & & & & & & \\
\hline dcGTX2 & - & - & 2.7 & 9.8 & 0.4 & 0.6 & - & - & 0.1 & 0.2 \\
\hline GTX3 & 0.8 & 0.9 & 0.2 & 0.8 & 0.3 & 0.6 & 0.8 & 2.5 & 0.4 & 0.9 \\
\hline GTX2 & 0.2 & 0.2 & - & - & - & - & 0.5 & 1.7 & - & - \\
\hline $\mathrm{dcNeo}+\mathrm{Neo}$ & 1.6 & 1.8 & 0.7 & 2.4 & 2.6 & 4.4 & 1.3 & 4.2 & 5.1 & 11.0 \\
\hline dcSTX & 0.3 & 0.3 & 1.6 & 5.9 & - & - & - & - & - & - \\
\hline STX & 0.2 & 0.3 & 2.9 & 10.4 & 0.6 & 1.1 & 0.3 & 1.1 & 1.3 & 2.9 \\
\hline C1 & 0.5 & 0.6 & 0.1 & 0.2 & 0.5 & 0.9 & 0.2 & 0.6 & 0.2 & 0.5 \\
\hline $\mathrm{C} 2$ & 16.7 & 19.0 & 1.9 & 6.8 & 21.7 & 37.0 & 17.2 & 57.7 & 22.7 & 49.3 \\
\hline Total & 88 & 100 & 28 & 100 & 59 & 100 & 30 & 100 & 46 & 100 \\
\hline
\end{tabular}



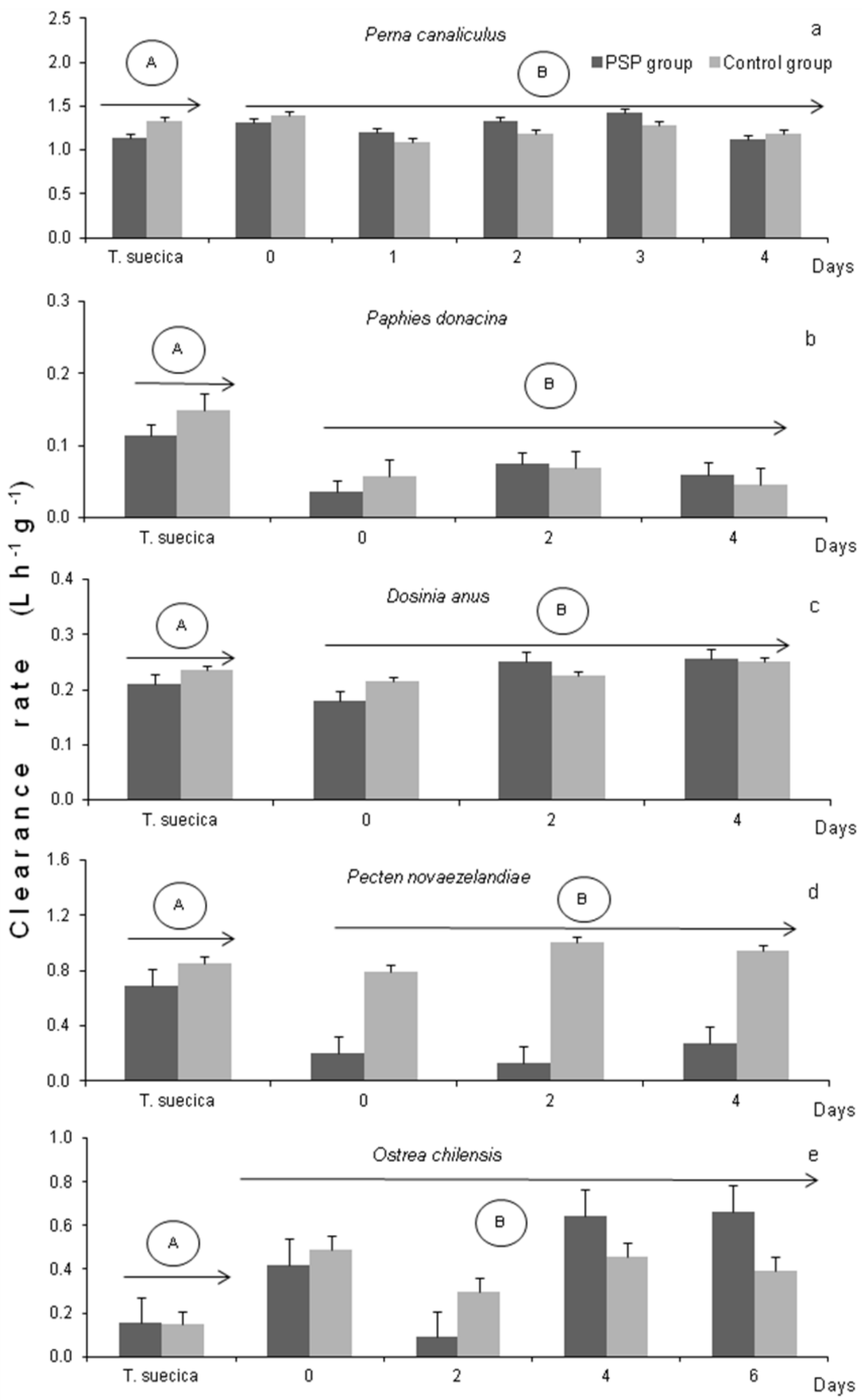

Figure 1: Clearance rates of bivalve species from New Zealand. A) The PSP and control groups were exposed to Tetraselmis suecica, B) The PSP group was exposed to Alexandrium tamarense (toxic) and the control group was exposed to Alexandrium margalefi (non-toxic). Values are means \pm SE. 